\title{
Chapter 2 \\ Territorial Governance of Schooling and Education in Rural Areas: Case Studies from Northern Germany
}

\author{
Holger Jahnke
}

\section{Introduction}

Schooling, understood as the provision of and participation in formal public education, has become a subject of discussion in many rural areas. Under the demographic pressure of shrinking pupil numbers in peripheral regions, a number of rural schools have been closed across Europe in recent years. In some countries, central national or regional education boards have accelerated this process by cutting support for small schools in peripheral regions; others, especially in the Scandinavian context, have followed a policy of decentralization by shifting resources and responsibility for schooling to the community level. Consequently, schooling has been (re) embedded into complex local processes of decision-making and resource distribution.

In this contribution I explore the interaction of two parallel processes, which researchers in different political and academic contexts have described as territorial governance on the one hand, and governance of schooling and education on the other. Whereas the former refers to a specific type of regional policy aiming at the development of a defined territorial entity such as a region, the latter refers to the application of new public management-strategies to the education sector by means of a politics of decentralization of power and growing autonomy of individual institutions or local communities. As will be shown, schools can be targets of both types of governance-territorial and educational.

In this chapter I analyze the impact these two distinct practices of governance have on schooling in declining peripheral areas. I have developed my conceptual ideas out of a series of empirical studies on schooling and education in rural areas conducted in the region of Schleswig-Holstein in Northern Germany between 2011 and 2018. Most of the data has been generated in applied research projects financed

\footnotetext{
H. Jahnke $(\bowtie)$

Department of Geography, Europa-University Flensburg, Flensburg, Germany

e-mail: holger.jahnke@uni-flensburg.de
} 
by the German federal government and the state government of Schleswig-Holstein, as well as some smaller projects carried out with the support of local authorities. The empirical material is based on quantitative data from official statistics, historical document analyses, as well as qualitative data mostly drawn from expert interviews. ${ }^{1}$

The Schleswig-Holstein region has been experiencing a strong demographic decline since the late 1990s, with a continuous acceleration throughout the 2000s. In the first decade of the 2000s alone, the number of children at elementary-school age dropped by roughly $20 \%$ in the regional average; in some rural counties, this process was particularly pronounced after 2005 , with a loss of up $25 \%$ in only 7 years (Jahnke \& Hoffmann, 2014, pp. 8-9).

My aim in this contribution is to highlight in more theoretical terms the territorial dimension of schooling in rural areas, which are currently characterized by demographic decline. I utilize the concept of territorial governance to analyze the territorial dimension of selected recent educational reforms in the German state of Schleswig-Holstein, which have decentralized decision-making power to local communities on the one hand and introduced mechanisms of competition between schools on the other. I stress the territorial consequences of three reforms and projects related to schooling and education-free parental school choice, all-day schooling, and educational landscapes - using two neighboring rural districts as case studies.

\section{The Territorial Dimension of Schooling}

Since the introduction of compulsory education in most European countries by the end of the nineteenth or the beginning of the twentieth century, schooling can be understood as a territorial practice. Though it was originally restricted to men and national citizens, it has been extended to all children living on the territory. The obligation for children to attend public schools also obliges the state to provide facilities and staff to insure equal access to high-quality education regardless of the location of residence. Researchers of early German geography of education have therefore been mostly concerned with the spatial accessibility of primary and secondary schools, especially in peripheral and remote areas.

The principle of compulsory education clearly expresses the state monopoly in controlling the processes and institutions of the education of all citizens. This is the case for Germany, where, for example, deschooling and homeschooling are prohibited and every child up to the age of 18 is obliged to attend a state school or a state-recognized private school. State-control over basic education is thus directly exercised by the schooling institutions-public or private—which must go through

\footnotetext{
${ }^{1}$ The data and material have been documented in detail in several (mostly German-language) reports, local case studies, and selected academic publications (Hoffmann \& Jahnke, 2017; Jahnke, 2015; Jahnke \& Hoffmann, 2012, 2013, 2017).
} 
a process of accreditation in addition to regular controls. On the other hand, compulsory education also forces the state to offer a public schooling opportunity in the geographical proximity of each child. This right to access adequate schooling — even though not legally defined-was a guiding principle for the expansion of the school system during the 1960s and 1970s, especially in peripheral and remote areas.

The responsibility for the provision of school education in Germany is traditionally divided between the regional ministry of education, the county administration, and the local level - the district or the municipality. In brief, the ministry of education is responsible for so-called inner school affairs, meaning all pedagogical concerns including the appointment of teachers and head teachers and the creation of the curriculum, which must pass through the regional parliament. School planning is mostly coordinated at the county level in collaboration between the county government and the respective administration of the ministry of education, which is also responsible for the assessment of school performance. The local-level actors of the municipality or district must provide school infrastructure and administrative personnel such as the secretary or the caretaker. Because education and culture have historically been the full responsibility of the regions, no federal ministry of education exists. In the past years, however, the federal government has tended to intervene indirectly in education policy through specific measures and initiatives to foster school development. For example, the introduction of all-day schooling was indirectly supported by federal investment funds for the construction of cafeterias or other architectural changes (Hoffmann \& Jahnke, 2017).

In this paradigm of centralized administration, the ministry of education and its representatives at the county level are fully responsible for the qualitatively adequate provision of basic schooling and education. The central administration controls the schools, the ministry of education selects the teachers, and the regional parliament determines the curriculum, whereas the ministry and its employees at the county level control its execution.

In terms of territorial organization, the provision of schooling is organized in fixed school districts, which means that pupils must attend a set school in their district. It thus binds pupils and parents to "their" school—at least at the elementaryschool level. At the same time, the organization by school district ensures that the entire territory is covered by an adequate provision of schooling. Apart from some exceptions-so-called school avoidance strategies - the only way to change schools is to change residency - an action taken only rarely, particularly in rural districts. So far, only two out of 16 regional states in Germany have introduced free parental school choice: Schleswig-Holstein and North Rhine-Westphalia.

Spatial school planning presupposes a sufficient number of pupils in each district. In recent years, the declining number of pupils in many rural areas has challenged the survival of many schools. The accelerated demographic decline and the consequent lack of pupils especially in rural elementary schools has made the maintenance of a school infrastructure with high quality standards a challenge for the educational administration. The elementary school is often one of a small village's last remaining infrastructures, so local politicians are very much concerned 
about school closures-giving rise to the widespread conviction that "with the school the village dies" (Jahnke \& Hoffmann, 2017). The presence of a school thus symbolizes the hope for a better demographic future - even in times of a rapidly shrinking population. Many mayors and local politicians therefore view young couples and families as a major resource for future development. This is one of the reasons why the provision of schooling has become part of a broader territorial governance strategy, particularly in rural areas.

\section{Territorial Governance and Education}

Researchers have mostly discussed the term territorial governance in the context of European territorial policy in relation to cohesion and convergence policies (Böhme, Zillmer, Toptsidou, \& Holstein, 2015; Lidström, 2007; van Well \& Schmitt, 2015). The concept first appeared in 2007 in EU documents as the "Territorial agenda of the European Union" (TAEU) (Petersen, 2016, pp. 10-11). It stresses on the one hand the cooperation of actors at different levels (supranational, national, regional, local) and different sectors (public and private in the fields of economy, science, administration, NGOs, and different political resorts) but on the other also its territorial dimension (Faludi, 2012). In a broad sense "territorial governance can be defined as the process of organization and coordination of actors to develop territorial capital in a nondestructive way in order to improve territorial cohesion at different levels" (Davoudi, Evans, Governa, \& Santangelo, 2008, p. 37).

In distinction from other forms of governance-such as educational governance-territorial governance does not target one specific domain but stresses the territorial dimension by managing territorial dynamics, assessing territorial impacts and delineating policy boundaries (Stead, 2014). Territorial governance's impact can transcend existing administrative boundaries, with new geographical entities emerging as a result of the process. Territorial governance processes themselvesdespite their integrative intentions - can then turn into new bordering practices.

The target of territorial governance measures is thus the territory — even though its boundaries are usually neither fixed nor clearly defined, as they can transcend existing administrative boundaries. According to Davoudi et al. (2008), the term territory itself is rather vague and can be understood in two different ways. On the one hand, territory can be considered as a set of (institutional) actors-public and private, collective or individual-present in a set space. Territorial governance in that sense is a form of organization and coordination of these actors. Governance, then, is the capacity to build an organizational consensus involving different actors in order to define common objectives and tasks, agree on the contribution of each partner to attain the objectives previously defined, and settle on a common vision for the future of their territory (Davoudi et al., 2008, p. 35).

On the other hand, territory can refer to territorial capital-a concept that has been developed by Dematteis and Governa (2005) and which comprises the following elements: a localized set of common goods and immovable goods, which 
are place-specific, as well as heritage goods, which are produced and stored over a long period on the territory (Dematteis \& Governa, 2005, as cited in Davoudi et al., 2008, p. 36). In that second sense of territory, territorial governance becomes more complex because it involves not only the (institutional) actors, but also the identity of the territory in its material, social, and cultural complexity. Territorial governance then needs to be understood

as the process of territorial organization of the multiplicity of relations that characterize interactions among actors and different, but non-conflictual, interests. This organizational dimension refers to the construction of a shared territorial vision, based on the recognition and valorization of the territorial capital to create sustainable territorial cohesion at different levels. (Davoudi et al., 2008, p. 37)

Territorial governance actions can take place on different scales-from the transnational to the local level-depending on the target of the governance action. Territorial governance actions are often related to organizational cooperation and dynamics at the transnational or the state level. They become more complex at the regional and local levels, where they demand a widespread participation and actions that refer to the specificity of the territory in terms of territorial capital (Davoudi et al., 2008, p. 45).

In both understandings, schooling and education facilities are part of any given territory and can thus be target of territorial governance action. Rural areas in northern Schleswig-Holstein have a very long tradition of schooling, which historically often goes back to the establishment of village schools by the church in the eighteenth century. These old school buildings are part of the region's cultural and architectural heritage. Some of them still host the local village school, whereas others are now used as local museums, preschools, restaurants, or other venues. Besides the school, other institutions of nonformal and informal education or culture can be part of the territory: the youth club, the adult teaching center, the fireworks, sports clubs, cultural associations, and the local library-but also individual actors like artists, writers, or any kind of teacher in the broadest sense. In this understanding, educational institutions play a rather important role in rural territories.

In a 2012 survey (Jahnke \& Hoffmann, 2012, 2013) on culture and education in rural districts in Schleswig-Holstein, almost all interviewed political stakeholders would only rarely consider schools and schooling as part of their territorial governance strategy, because they were-and still are-formally directed and controlled by the regional ministry of education. However, the same interviewees felt slightly more responsible for the educational institutions of the nonformal sector, because some of them-such as kindergartens-were their direct responsibility. However, the idea of provision of education was still dominant. The stakeholders' major concern regarding future development was how to manage the demographic transformation with an ageing population in increasing need of medical and transportation facilities. Territorial governance was thus strongly linked to demographic transformations, which needed to be managed. It was only when local schools were threatened with closure that local politicians would develop an interest in school and education. In a general climate of growing political attention 
for education, which was fostered by parents mobilizing against school closure, schooling and education became part of the local development strategy.

According to the respective concepts of territory, two different approaches to the local territorial governance of education can be distinguished: The supporters of the first take into account the educational institutions within a given territory - such as a district - and try to coordinate their actions towards a common goal. This is in essence the idea of the so-called local educational landscapes, which I will discuss later on in this text. The other is a more place-based approach, whose supporters consider educational institutions as part of the place identity and the cultural heritage. Researchers of territorial governance of education in this second sense would pay more attention to the relations of the educational institutions and actors with the specific territory in its material, social, and cultural dimensions. Territorial governance action in the first sense is more concerned with coordination and organization of educational institutions and thus impacts on the level of territorial representation, which will eventually lead to a common orientation; in the second sense, actors might have to intervene more directly in the educational institutions, related processes, and relations in the territory und thus in the territorial capital in its different dimensions itself. It needs to be considered, however, that educational institutions and processes themselves, especially public schools, are the target of another governance process, which researchers usually refer to as educational governance, or more specifically governance of schooling.

\section{From School Planning to Governance of Schooling and Education}

The term educational governance has been used in the Anglo-American context since the late 1970s in the general climate of neoliberal state reforms (Sergiovanni, Burlingame, Coombs, \& Thurston, 1980). It is a part of the new public management strategy, a term that describes the introduction of management mechanisms in different sectors of public administration. Educational governance is often connected to a decentralization of power and decision-making from the central administration (i.e., the ministry of education) to the local authorities or the individual institutions. Educational governance thus usually involves institutions at different levels - state, regional, and local. Most of these institutions are public, but may involve private actors as well.

A vast amount of research has been published around the topic of educational governance, especially in the German and Austrian context (i.e., Altrichter, Brüsemeier, \& Wissinger, 2007; Altrichter \& Maag Merki, 2010; see also Chap. 4 by Altrichter in this volume). In terms of terminology, the distinction between educational governance, governance of education, school governance, and governance of schooling is not always very clear. In this chapter, I use the term educational governance or governance of education to refer to governance processes that theoretically involve all actors from the educational field, whereas governance 
of schooling more specifically refers the processes and practices directly related to schools, thus including both formal and nonformal education that takes place in the school or is organized by the school; it includes afterschool activities.

In Germany, and more specifically in Schleswig Holstein, school legislation, school reforms, and new school development programs at different levels offer the necessary conditions for a growing freedom of choice and decision-making for schools and families. At the same time, a general shift of responsibility from the central state ministry of education to the local authorities and the individual school institution can be observed. However, because schools were not supplied with sufficient financial and human resources, they could only acquire new resources by applying for additional funding, and cooperative endeavors were opened and resources were made available only through specific projects and programs.

From a geographic perspective, many of these political measures had an implicit territorial dimension. In the following, I will discuss three different educational initiatives from the federal state or the regional state government in order to highlight how schooling has slowly shifted from state provision of schools towards governance of schooling.

\section{Introducing Competition Among Schools: The Schleswig- Holstein School Act 2007}

The 2007 Schleswig-Holstein School Act (Schleswig-Holsteinisches Schulgesetz vom 24.1.2007) had a decisive influence on the shift from school planning to governance of schooling, as it introduced elements of free market competition at the level of elementary schools for the first time. Most important was the introduction of free parental choice, which allows parents to send their children to the elementary school of their choice. If they pick a school in another district, the sending municipality must pay a share of the additional schooling cost to the receiving municipality or district. Despite the demographic decline that had already been perceivable in many rural areas, the minimum number of pupils in each elementary school was generally fixed at 80 , with the possibility of administratively uniting smaller schools. In order to profile their school in this new competitive context, head teachers were given the opportunity to seek sponsoring, develop specific school curricula, and exercise some influence on the selection of teaching staff. Initially, there was little evidence that these changes led to a general reorientation of parents' school choice in rural areas; however, they indirectly transformed parents and children into school clients. As a consequence, schools, and especially head teachers, had to invest in marketing activities such as the setting up of webpages, open school days, and information campaigns. At the same time, the ministry did not provide the schools with additional resources for these supplementary — and nonpedagogical-activities. Sometimes it was the parents who set up the webpage, helped to apply for additional funding, or supported the 
head teachers in these activities. In all cases, the supplementary "competition costs" depended on the local resources-from within or outside the school. In some cases, the actors on the municipal level, as school providers, tried to offer support to their school (Jahnke \& Hoffmann, 2014).

\section{Opening Schools to Noneducational Actors: Afterschool Activities}

Another major reform was the introduction of all-day schooling, which was initiated by the federal government and then put into practice through the regional ministries (Coelen \& Rother, 2014; Kagelmacher \& Hollmer, 2010). As a result of the so-called Pisa shock, which pointed to Germany's rather weak results especially in terms of social mobility through education, demands for all-day schooling rose considerably. In most states, however, afternoon schooling was set up on a voluntary basis and only few schools were fully turned into all-day schools. In SchleswigHolstein, obligatory all-day schooling was introduced only in social hotspot areas of big cities, whereas rural schools, in particular elementary ones, were all-day only on a voluntary basis. The federal government did provide funding for the construction of school cafeterias or other necessary renovations of the school buildings, but schools needed to apply for it. However, funds for teaching staff salaries were not made available. The ministry only financed the position of a coordinator for the organization and administration of the afterschool activities, whereas the teaching staff was hired on a voluntary basis - they only received a financial compensation for their expenses. Accordingly, most schools had to rely on the local resources of associations, sports clubs, and other volunteer-based structures to cover the necessary hours. In addition, the ministry's financial support was rather symbolic, as it was calculated on the basis of pupils' actual participation, which from the very beginning turned out to be weak and irregular. As a result, the introduction of allday schooling, which began as a groundbreaking reform of the German school system, turned out to be based mainly on local resources. Both economic and cultural capital are unevenly distributed, especially in rural areas (Jahnke \& Hoffmann, 2017).

\section{Territorialization of Schooling and Education: Educational Landscapes}

The third initiative-the creation of educational landscapes (Bildungslandschaften) - also came from the regional state of Schleswig-Holstein, but similar concepts have been developed in other regions as well. The reformers intended to coordinate all institutions related to education in a very broad senseformal, nonformal, and informal—within the same territory (Emmerich, 2017; 
Olk \& Schmachtel, 2017). The central pedagogical idea was to facilitate children's as well as other people's access to these offers and activities. In many cases, these educational landscapes were centered around the local school(s) and the organization of afterschool activities was a major driver in most projects, as they depended on the collaboration with other providers. In Schleswig-Holstein, reformers promoted this idea since 2009 through three different calls, in which schools and local authorities could apply for initial funding to set up a network. Only three educational landscapes were funded in the first round, whereas more localities were supported in the later waves. The funding was limited to the coordination of the different institutions as well as the organization and administration of the network itself. The extension of the network was not strictly limited in geographical terms, so that partners could be acquired from outside the administrative boundaries of the applying district or municipality. At the same time, schools or education providers could also opt not to join the network, so that the geographical extension of the network could differ from the area of the municipality or district. The emergence of these new spatialized education-based entities with their own administrative centers can thus be characterized as the terriorialization of schooling and education. Although this shift lead to the emergence of new educational territories, the majority of municipalities in Schleswig-Holstein today still do not belong to any network. As a consequence, the homogenized state school provision has been overlaid by a patchwork of isolated local educational landscapes - with some educational flagships and a high number of areas, districts, and municipalities that do not appear on this map.

The mentioned reforms can be understood as different steps in a form of educational governance which on the one hand gives more decision-making power to the local and institutional level, but on the other hand also adds new tasks and responsibilities. The free parental school choice set the basis for schools increasingly competing for children in a period of rapidly shrinking pupil numbers. Part of the assessment of school quality was ultimately left to the parents who, through the means of school choice, had the strongest influence on the closure of a school.

Political stakeholders promoted the introduction of afterschool activities as a means of providing all-day schooling for all children, ensuring less influence of social background on education, and thus reducing social inequalities. In practice, however, it implied introducing voluntary afterschool activities only for schools that applied for the funding - federal funding that, as already mentioned, was rather symbolic and inadequate. To keep their activities running, schools still depend on volunteers-usually, none of the late afternoon hours are taught by professional teachers. This also means that the quality depends entirely on the material, social, and cultural resources available locally.

The third instrument to promote education — the educational landscapes—clearly follows the idea of territorial governance as developed at the beginning of this chapter, but is limited to educational resources in a very broad sense. The idea of promoting educational landscapes explicitly brings the territorial governance of schooling into a political practice. In the name of better local educational provision, all actors in the field are being coordinated and organized in order to mobilize all 
educational resources available and to promote the newly emerging territories. A territory's profile can become an important factor in the competition between rural municipalities for demographic stability, as it can even attract children and families from neighboring communities.

The state funding itself follows the traditional structure of governance: Financial support is basically limited to organizational costs as well as the position of a coordinator, though only for a few years, after which he or she is expected to be employed by the local district or municipality. The same strategy applies to the coordinator of afterschool activities-instead of hiring teachers and qualified pedagogues, the state finances a coordinator, who is in charge of mobilizing local human and cultural resources on a voluntary basis.

Both initiatives-the afterschool activities and the educational landscapes-primarily aim at strengthening the schools' performance by means of mobilizing the multiple local educational resources in order to extent the time of schooling to the afternoon and to compensate for the lack of professional teachers and pedagogical staff. In theory, the catchment area of these resources is unlimited in both space and quantity, so that the emerging educational landscapes can be extended and gradually form their own territoriality, transcending administrative boundaries and integrating educational actors and institutions from neighboring districts.

\section{Integrating School Development into Local Territorial Governance: Concrete Examples}

Apart from their impact on education, the three mentioned reforms have also triggered concrete territorial consequences. As the case studies of two neighboring districts-Mittelangeln and Süderbrarup—show, educational and school development have had an impact.

\section{Mittelangeln: A Model Educational Landscape in the Center of a Territorial Development Strategy}

The municipality of Satrup in the district of Mittelangeln was among the first municipalities to apply for support during the first wave of the educational landscapes policy in 2009. Based on the initiative of a young and highly dedicated coordinator, the municipal actors succeeded in creating a strong and well organized network of cultural and educational institutions in the formal, nonformal, and informal education sector under the heading "Bildungslandschaft Satrup." The network included two secondary schools and their common afterschool activities, although it was started and initiated by the local authorities, especially the social and youth workers. The coordinator, together with the local authorities, became very creative 
in channeling other project funds into the network, such as funding for family centers and a financial educational support program for families in need. Interviews carried out in 2012 revealed that local representatives initially considered education the responsibility of the regional state ministry. As the network's size and visibility grew, however, the educational landscape became a local trademark and eventually moved to the center of local marketing. In the beginning, network partners were mostly located in the central municipality, but with time the educational landscape rapidly extended. In 2013, when the municipality of Satrup and two other municipalities were merged into the new municipality Mittelangeln, the educational landscape's name was changed to "Bildungslandschaft Mittelangeln." Even after the municipal reform, Mittelangeln remains a small rural town with no more than around 5000 inhabitants. However, education in its different forms-including care services-has moved to the heart of the local identity and become an important draw. Even the official webpage of the municipality directly points to the educational landscape, which now has its own central office at the local adult education center (www.gemeinde-mittelangeln.de). The educational landscape adds to the attraction of the municipality for young families. In addition, the freedom of school choice has contributed to the fact that even children from neighboring districts started attending the schools in Satrup, due to their good reputation. Through the coordination and networking of all institutions and offers in the field of formal, nonformal, and informal education and care, the educational landscape has become a key part of territorial identity in the municipality and beyond.

\section{Süderbrarup: Preventing Decline Through Centralization of Elementary Schooling}

A very different case is the neighboring district of Süderbrarup, a rather peripheral area that has been hit by rapid demographic decline, especially of children at elementary-school age. The district is composed of 13 municipalities, which have historically all been equipped with at least one elementary school. Many German refugees from the former German territories in Eastern Europe were allocated to rural areas after World War II, and many new schools were built in Süderbrarup in the early 1950s. At its peak in this decade, the district counted 15 elementary schools-most of them in traditional historical school buildings established by the church since the eighteenth century. According to the statistics from the district administration provided in 2016, the number of school children in the district had declined sharply: In only 7 years (2008-2015), the number of children at elementary school age dropped from 563 to 361 . During a period of about 50 years, 10 out of 15 schools had to be closed; only five elementary schools were left in 2013 , and further decline was predictable. The district administration at the time therefore predicted the closure of two more schools. In addition to demographic decline, some elementary schools on the district's periphery suffered from the already mentioned free parental school choice. 
The neighboring district of Mittelangeln was particularly affected, as school buses there were running to bring children to the upper secondary school in Satrup, causing some parents to send their children to the elementary school there as well. This outmigration eventually threatened the survival of all elementary schools in the peripheries, so the district administration opted for a fairly radical solution to interrupt the vicious circle of decline. They designed a new "education campus" with a central elementary school for up to 330 children, hoping that the rather prestigious architecture would improve the quality and visibility of the educational offer. At the same time, they reorganized the bus system within the district in order to guarantee every child a maximum of 20-min bus travel time to the school. The idea was to not only stop out-migration of children at elementary-school age, but also to strengthen the position of their own secondary school, which due to its tradition as a lower secondary school (Hauptschule) suffered from a relatively negative reputation-especially in comparison to the schools in Satrup. Due to the considerable size of the new central elementary school, the district decided to close all other elementary schoolseven those that theoretically could have survived despite the minimum number of pupils imposed by the ministry. In this case too, schooling became central for territorial development policy - as a reaction to the shining attraction of the competing educational landscape in the neighboring district of Mittelangeln.

In both cases it has been interesting to observe the changing attitude of local politicians in the period between 2010 and 2015. It was in those years that the consequences of the 2007 school act - namely free parental school choice, a minimum number of pupils, and financial compensation-became apparent. Local politicians were confronted with the threat of actual school closures with all its consequences: Politically, parents were usually expressing their opposition to school closure, and economically the sending municipalities had to cover both the expenses for the receiving school and the cost for their own school infrastructure. Even in the case of school closure, empty school buildings still demanded rather high expenses for heating and maintenance, as it is almost impossible to find new tenants for a school building in peripheral rural areas. This has been a major concern in Süderbrarup. Satrup-Mittelangeln was one of the first municipalities to recognize the importance of formal, nonformal, and informal education for future territorial development, whereas in Süderbrarup the centralization of schooling within the district is an attempt to reorganize the district's territorial coherence.

\section{Conclusion}

As the examples have shown, schooling in rural Schleswig-Holstein has to some extent become part of local territorial governance-especially because demographic decline has become a major concern and barrier for future development. Recent school legislation as well as educational development policies have set the frame for a territorial governance of schooling, where education and population policies are merged in the name of territorial and school competition. 
The three reform measures discussed in this text-namely the introduction of parental school choice and other market mechanisms, the option of all-day schooling, and the introduction of educational landscapes - have led to an opening of the schools and a weakening of the strict boundaries between state elementary schools and their local environment. Only a few years ago, local stakeholders fundamentally perceived the local elementary school as a state institution directed by the central regional ministry of education; now, local actors have opened up those same schools and integrated them into local development strategies. Local authorities do more than invest in and support their school-they even make it central to local development strategy: In Mittelangeln the educational landscape has become a keystone of territorial identity, whereas in Süderbrarup the new education campus has led to a spatial, material, and social reorganization of the district territory.

I have presented two different examples of local governance of schooling and education: The actors of the first engage in the cooperation and coordination of existing educational institutions and activities in a territory without hard boundaries; those of the second use the spatial centralization of all schools in the district as a trigger to reinforce and reorganize the territorial structure of the district- - from a decentralized agglomeration of different municipalities to a district with a unique center. In terms of territorial governance, they go along with the two concepts of territory that I introduced at the beginning of this chapter: In the first case, the territorial governance actors target the organizational dimension of educational institutions in the territory, whereas in the second case, they directly invest in - or disinvest from-the assets of territorial capital-such as school architecture, infrastructure, and public transportation flows.

Researchers of the geography of schooling and education have often praised the recognition of schooling as a means of development as an achievement-and the growing importance of and political support for education clearly underlines this idea. In this contribution, however, I have offered a more critical perspective of some processes of territorial governance of schooling. If a local elementary school is being integrated into territorial strategies to cope with demographic crises, if the development of a school depends on the engagement and networks of single coordinators and local political support, if part of the teaching is done by underfinanced nonprofessionals or volunteers, if the quality of teaching increasingly depends on the availability of local resources-what does this imply for the future provision of schooling and education in rural areas, especially in terms of spatial equality, equal opportunities, and participation in society at large?

From the case studies in Schleswig-Holstein it becomes evident that a new geography of schooling and education in rural areas will eventually emerge from this type of territorial governance of schooling and education. Territorial competitionand school competition-will probably lead to more diversity among the schools in the region, and a more place-based offer of schooling is to be expected. The quality of the respective local educational provision, however, will reflect the economic, social, and cultural resources of each local reality, and will thus influence the future perspectives of the children who attend it. 


\section{References}

Altrichter, H., \& Maag Merki, K. (Eds.). (2010). Handbuch Neue Steuerung im Schulsystem [Handbook new governance in the school system]. Educational Governance: Vol. 7. Wiesbaden, Germany: VS Verlag für Sozialwissenschaften. https://doi.org/10.1007/978-3-531-92245-4

Altrichter, H., Brüsemeister, T., \& Wissinger, J. (Eds.). (2007). Educational governance: Handlungskoordination und Steuerung im Bildungssystem [Educational governance: Coordination of actions and steering in the education system]. Educational Governance: Vol. 1. Wiesbaden, Germany: VS Verlag für Sozialwissenschaften. https://doi. org/10.1007/978-3-531-90498-6

Böhme, K., Zillmer, S., Toptsidou, M., \& Holstein, F. (2015). Territorial governance and cohesion policy. Brussels, Belgium: European Union. https://doi.org/10.2861/941994

Coelen, T., \& Rother, P. (2014). Ganztagsschulen in Bildungslandschaften [All-day schools in educational landscapes]. In T. Coelen \& L. Stecher (Eds.), Die Ganztagsschule: Eine Einführung (pp. 79-96). Weinheim, Germany: Beltz Juventa.

Davoudi, S., Evans, N., Governa, F., \& Santangelo, M. (2008). Territorial governance in the making: Approaches, methodologies, practices. Boletín de la A.G.E, 46, 33-52. Retrieved from https://www.age-geografia.es/ojs/index.php/bage/article/viewFile/677/631

Dematteis, G., \& Governa, F. (Eds.). (2005). Territorialità, sviluppo locale, sostenibilità: Il modello SLoT [Territoriality, local development, sustainability: The SLoT-model]. Milan, Italy: Franco Angeli.

Emmerich, M. (2017). Regionalization of education. In A. Million, A. J. Heinrich, \& T. Coelen (Eds.), Education, space and urban planning: Education as a component of the city (pp. 279-287). Cham, Switzerland: Springer. https://doi.org/10.1007/978-3-319-38999-8_27

Faludi, A. (2012). Multi-level (territorial) governance: Three criticisms. Planning Theory \& Practice, 13, 197-211. https://doi.org/10.1080/14649357.2012.677578

Hoffmann, K., \& Jahnke, H. (2017). Schulische Bildung zwischen staatlichem Auftrag und ehrenamtlichem Engagement: Zur Rolle des offenen Ganztagsangebots in den ländlichen Räumen Schleswig-Holsteins [School education between state mission and volunteering: The role of all-day school offers in the rural areas of Schleswig-Holstein]. Berichte: Geographie und Landeskunde, 91, 217-236.

Jahnke, H. (2015). Machbarkeitsstudie zum Vorhaben "Bildungscampus” im Amt Süderbrarup [Feasibility study for the "Education Campus" project in the district Süderbrarup] (Unpublished manuscript).

Jahnke, H., \& Hoffmann, K. (2012). Sachstand der Befragung zu Kooperationen im Bereich Bildung/Kultur: Eine qualitative Datenerhebung in ausgewählten Amtsbereichen des Kreises Schleswig-Flensburg [Report on the inquiry on cooperations in the education/culture sector: A qualitative data collection in selected districts in the county Schleswig-Flensburg] (Unpublished report).

Jahnke, H., \& Hoffmann, K. (2013). Handlungsorientierungen auf der Basis qualitativer Analysen ausgewählter Best-practices bestehender Kooperationen in den Ämtern, Städten und amtsfreien Gemeinden des Kreises Schleswig-Flensburg [Guiding principles based on qualitative analyses of selected best practices of existing cooperations in the districts, cities and independant municipalities in the county Schleswig-Flensburg]. Retrieved from https://www. schleswig-flensburg.de/media/custom/146_8677_1.PDF?1390222306

Jahnke, H., \& Hoffmann, K. (2014). Die Zukunftsfähigkeit der Grundschulen in den ländlichen Räumen Schleswig-Holsteins [Future viability of elementary schools in rural areas of Schleswig-Holstein]. Retrieved from https://www.amt-bokhorst-wankendorf.de/assets/studiegrundschulen.pdf

Jahnke, H., \& Hoffmann, K. (2017). Organized after-school activities at the intersection between education and municipalities in rural areas. In A. Million, A. J. Heinrich, \& T. Coelen (Eds.), Education, space and urban planning: Education as a component of the city (pp. 339-347). Cham, Switzerland: Springer. https://doi.org/10.1007/978-3-319-38999-8_33 
Kagelmacher, S., \& Hollmer, H. (2010). Die Ganztagsschulentwicklung in Schleswig-Holstein [The development of all-day schooling in Schleswig-Holstein]. In S. Appel, H. Ludwig, \& U. Rother (Eds.), Jahrbuch Ganztagsschule 2010: Vielseitig fördern (pp. 167-177). Schwalbach, Germany: Wochenschauverlag.

Lidström, A. (2007). Territorial governance in transition. Regional \& Federal Studies, 17, 499-508. https://doi.org/10.1080/13597560701691896

Olk, T., \& Schmachtel, S. (Eds.). (2017). Educational governance in kommunalen Bildungslandschaften [Educational governance in municipal educational landscapes]. Weinheim, Germany: Beltz Juventa.

Petersen, J. (2016). European territorial governance: Methode europäischer Raumentwicklung [European territorial governance: A method for European spatial development]. Studien zum Völker- und Europarecht: Vol. 137. Hamburg, Germany: Dr. Kovac.

Sergiovanni, T. J., Burlingame, M., Coombs, F. D., \& Thurston, P. W. (1980). Educational governance and administration. Englewood Cliffs, NJ: Prentice-Hall.

Stead, D. (2014). The rise of territorial governance in European policy. European Planning Studies, 22, 1368-1383. https://doi.org/10.1080/09654313.2013.786684

van Well, L., \& Schmitt, P. (2015). Understanding territorial governance: Conceptual and practical implications. Europa Regional, 21(4), 209-221. Retrieved from https://nbn-resolving.org/ urn:nbn:de:0168-ssoar-457127

Open Access This chapter is licensed under the terms of the Creative Commons Attribution 4.0 International License (http://creativecommons.org/licenses/by/4.0/), which permits use, sharing, adaptation, distribution and reproduction in any medium or format, as long as you give appropriate credit to the original author(s) and the source, provide a link to the Creative Commons license and indicate if changes were made.

The images or other third party material in this chapter are included in the chapter's Creative Commons license, unless indicated otherwise in a credit line to the material. If material is not included in the chapter's Creative Commons license and your intended use is not permitted by statutory regulation or exceeds the permitted use, you will need to obtain permission directly from the copyright holder.

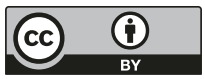

